\title{
COL F.F. PIENAAR'S BOER WAR DIARY
}

\section{(PART I)}

\author{
BRIG J.H. PICARD, SM*
}

In 1902, Filip Pienaar, a young Boer officer in exile at the Monastery of Tomar in Portugal, recorded his Boer war experiences. These were published by Methuen in 1902, under the title With Steyn and De Wet. The book was banned one month after publication. The author, Lt Col F.F. Pienaar, later joined the Union Defence Force, served in the German South West Africa Campaign and later became South Africa's first ambassador to Portugal in 1939, from where he also conducted correspondence with his cousin General Dan Pienaar. As a son-in-law of the late F.F. Pienaar, it is my privilege to reproduce part of his Boer War experiences. Pienaar's account is one of the first books on the Boer War and covers several eye-witness accounts at that time.

\section{EARLY CAMPAIGNS}

After the expedition made by the ZuidAfrikaansche Republiek Politie (ZARP) in 1897, to arrest King Bunu on a charge of murder,' young Pienaar, a member of the commando serving the warrant, was transferred by the ZA Republiek Telegrafiedienst from Johannesburg to Pilgrim's Rest. Pilgrim's Rest was a quaint little one-street village near the Portuguese border, one of the oldest alluvial diggings of the early days and now the centre of an important mining district.

The Second Anglo-Boer War broke out on 11 October 1899. At Pilgrim's Rest, Pienaar heard that "our commandos had invaded the enemy's territory in every direction", and news of the pre-

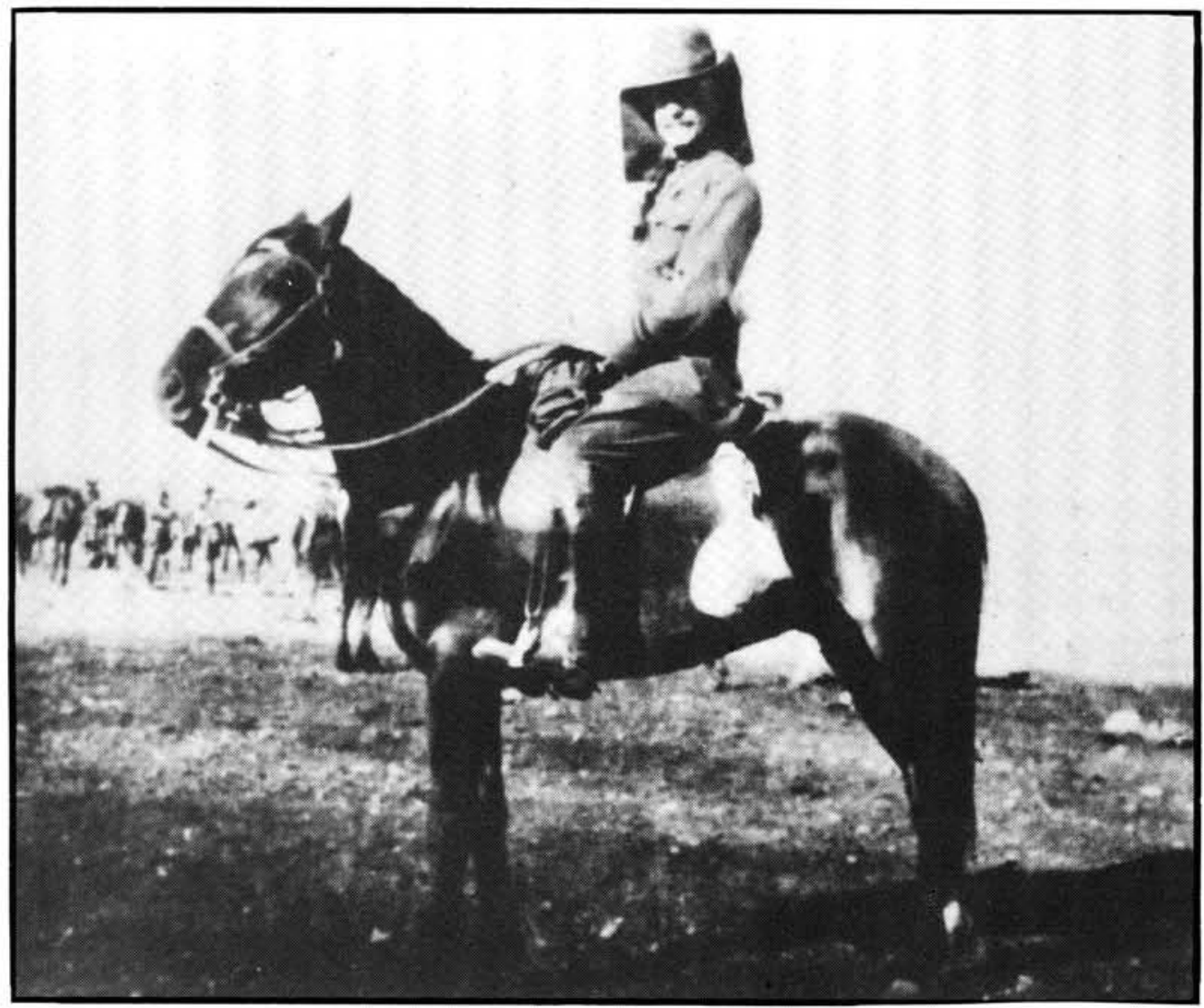

F.F. Pienaar, officer of ZAR mounted commando during arrest of Bunu, Swazi paramount chief. Swaziland expedition (1879). 


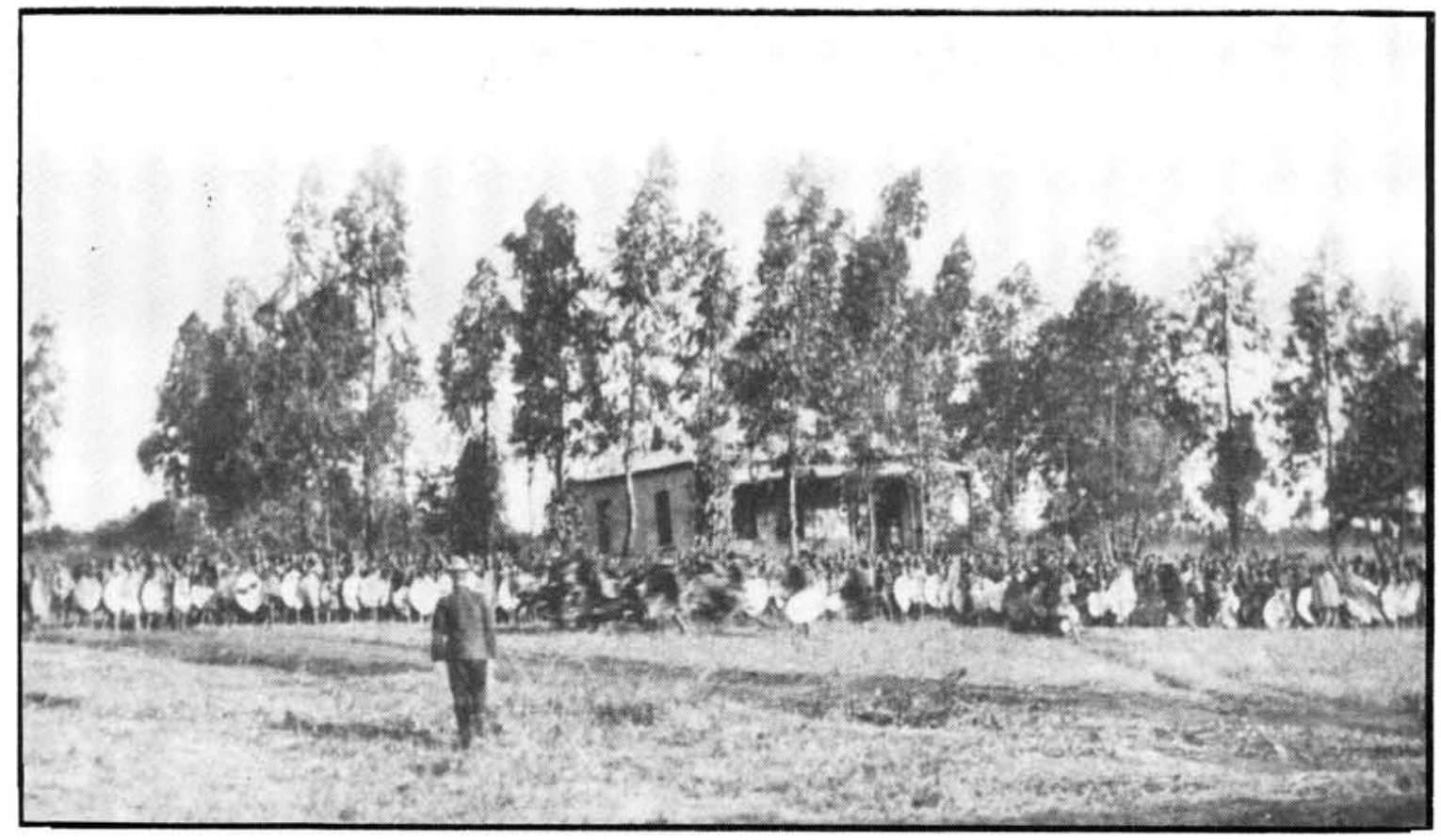

The Swazi paramount chief Bunu appears before the court at Bremersdorp (now Manzini) in 1897. F.F. Pienaar, officer of the ZAR (back to the camera) walks between the court building and the Post Office to send a signal to the authorities concerning Bunu. (Photograph taken by A.M. Miller snr, Swaziland Expedition.)

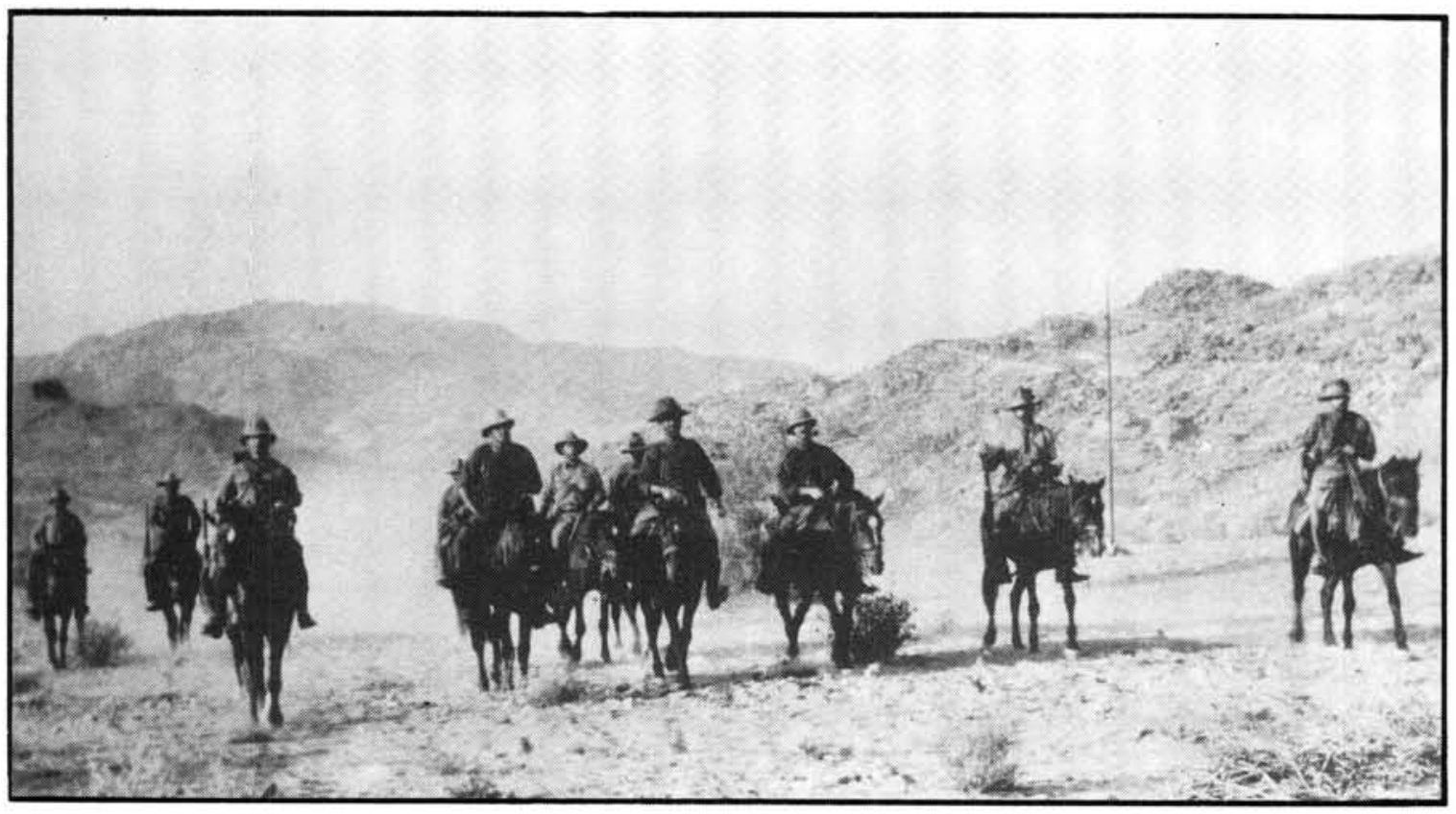

Swaziland expedition; mounted ZAR Commandos (1897) Pienaar fourth from right in front.

liminary engagements were awaited with breathless interest. The male inhabitants of the village often spent entire nights under the verandah of the telegraph office, and, Pienaar wrote. "the importance of the telegraphist suddenly grew almost too great to bear with becoming modesty". On 21 October 1899, the battle of Elandslaagte took place. The Lancers and Dragoons under the overall command of General White, charged the unprepared Boers. The long list of the fallen depressed the men gathering around the post office in Pilgrim's Rest. Name after name, friend after friend. The fallen included Pienaar's uncle, General J.H.M. Kock (1834 - 1899), Major Hall and Advocate Lt Dr H.J. Coster (1865 - 1899), the Commander of the "Hollander Corps".

Within a week, reinforcements were dispatched from the district and young Flippie Pienaar, having obtained a few weeks leave of absence, accompa- 
nied them. He found himself in an interesting band. Two hundred strong, they were farmers, clerks, schoolmasters, students, an Irishman, a Hollander, a German and a Jew. Every mess possessed one or two ox-wagons, carrying a water tank, portmanteaux, trunks, foodstuffs and ammunition. They made about twenty miles daily, passing through Lydenburg. Machadodorp. Carolina, and Ermelo, and reached Volksrust on the fourteenth day. They followed the general line of the Boer invasion of Natal.

During the march they learnt that heavy fighting had taken place in $\mathrm{Na}$ tal. Dundee was taken and Ladysmith besieged, and a strong commando had actually made reconnaissance as far south as Estcourt.

Pienaar, after recuperating from saddle bruises at Volksrust, approached General Piet Joubert for a special passport enabling him to return when his leave expired. Joubert said:

"Others want leave to go home: you ask for leave to come to the front. But your time is so short, it is hardly worth while. Still, I am glad to see such a spirit among you young people".

Then he signed the document and shook Pienaar by the hand. Pienaar entrained that afternoon, slept in the carriage at Newcastle, reached the station nearest Ladysmith the following day, detrained, rode into the camp and reported for duty. The same night he went on outpost duty.

His chief concern was whether he, as a novice, would conduct himself well in the first encounter. An old campaigner asked him: "Tell me, how do you feel" "Well, rather nervous". "Ah, Now I can tell you that a man who feels nervous before a fight is all right, because he has some idea of what he is going to meet. It is the reckless recruit that often proves a coward. $\mathrm{He}$ fancies it a mere bagatelle, and finds out his mistake too late". This encouraged Flip because he felt anything but reckless.

A few days later, when Pienaar and a few companions reached the spot where they were to stand guard during the night, they dismounted and two men went forward on foot to reconnoitre. After a while they brought back the news that the enemy was approaching in force. After having been sent out again for confirmation, they returned, saying there could be no doubt about the matter: "We heard the rumble of an approaching train, the march of cavalry, and saw the glint of arms between the trees!"

A man was instantly despatched to alarm the main laager, the rest following slowly. He returned with a further twenty-five men and an order that they were to return instantly to their posts.

Pienaar and his group felt that there was no fun in attacking massed troops with fifty men. They retraced their steps to a kraal where they had helped to feed a sick Black man. Two men crept up close and came back to say the place was full of English. Leaving the horses in charge of a few men, the others crept forward and surrounded the kraal. Each sought a suitable shelter and laid himself down to await the dawn. It was then about midnight. The next four hours passed very slowly: lying there in the cold in expectation of a desperate struggle in the morning.

"We thought how brave we were", Pienaar wrote, " ... and how sorry our general would be when he heard how we had all been shot down to a man and how in after years this night attack of ours would rank with the charge of the Light Brigade. We hoped Chamberlain would die soon after us, so that we could meet his soul in the great $\mathrm{Be}$ yond to drag it through a sieve".

When it grew light, to their surprise, they found that there was not an Englishman near. It had been a false alarm and all their valour had been for nothing! This kind of alarm became rather frequent.

A burger woke up one night to find himself being shaken roughly and some one shouting in his ear: "What are you doing? Get up! Don't you hear the alarm?" "Yes, another false one, I daresay," turning over for another nap. Happening to open his eyes, he 
became aware for the first time that he was speaking to none other than General Joubert himself! The poor fellow did not argue the point any further. but fled into the night, glad to get off at that price.

Pienaar and his companions remained in the vicinity of Ladysmith for some time. One morning, having heard that a serious engagement had taken place on Lombard's Kop, he rode in that direction and met two Boers on horseback.

"Môre, nefies."

"Môre neef. Where are you from?"

"The Telegraph service, and nefies?"

"Of the Artillery."

"Something happened up there last night?"

"Yes. The English came and blew up our Long Tom!"

That incident was blamed on the absence of the guard but there was a strong suspicion of treason. During the ensuing court martial two officers were only suspended from duty.

A few days later Pienaar went to see his brother who was stationed on Pepworth Hill, some miles to their right. $\mathrm{He}$ belonged to the Artillery Cadets, all of whom were dispersed amongst the various guns at the beginning of the war, in order to give them practical experience. Of the four that were attached to this gun two had already been wounded.

It was glorious for Pienaar to see these lads of fifteen and sixteen withstanding the onslaught of the mighty naval guns on a daily basis. The rocks around their howitzer were torn by lyddite, and the ground strewn with shrapnel bullets. The lads were quite chirpy.

"The British say we are trained German gunners. Quite a compliment to Germany!" the one youngster grinned. "And I", said another, inflating his chest "am a French or Russian expert!"

They showed Pienaar how they crushed their coffee by beating it on a flat stone. Their staple food was bully beef and hard biscuits.
"If only we had some cigarettes," they said, "how happy we should be! Last week we got some sugar, enough for two days; we are so sick of black, bitter coffee!" 2

They had no tents and had to find the best possible shelter under tarpaulins stretched out between the rocks. Pienaar went back in the pouring rain. The flap of the tent was opened and he was ordered to turn out and stand guard. Drawing on a soaking pair of heavy corduroy breeches in the middle of the night and sitting in these on an antheap for a couple of hours, with a chilly rain falling, is a sobering experience.

In the morning Pienaar's new friends, the young cadets, came riding into the camp. Their howitzer had been blown up. The state of their ragged uniforms showed the hand-to-hand nature of the struggle that had taken place. One of them told the story:

"We heard someone climbing the hill in the night, and challenged. It was the British. They shouted 'Rule Britannia!' and rushed up to the top. We fired into them but we were too few and were forced aside by sheer weight of numbers. One of the artillery men was dragged by the leg from his sleeping-place. He shook himself free and bolted. The soldiers formed a square round the gun, charged it with guncotton, shouted 'stand back!' and the next moment our gun came crashing through the sky. Then the enemy retired. But the Pretoria Commando waiting for them intercepted their retreat and made them pay dearly enough for their exploit". 3

One day the scouts brought a war correspondent into the camp. His story was that he had wandered out of Ladysmith with a packet of newspapers, "merely to exchange notes and to challenge you to a cricket match!" squatting on the ground, crowds of bearded Boers gazed at him with fierce interest. The correspondent looked most uncomfortable and no wonder, for the word "spioen" (spy) 
was often uttered. His colour was pale green and his teeth chattered audibly. $\mathrm{He}$ was subsequently sent to Pretoria and thence "exiled" to civilisation, via Delagoa Bay.

On the same day three Blacks bearing British dispatches, were captured. As these runners were giving considerable trouble, it was decided to execute one and send the other to spread the news among their friends - black and white.

The grave was already dug when General Joubert, always opposed to harsh measures, decided to spare his life. The contrast between the martial bearing of this black and that of the young war correspondent was striking. ${ }^{4}$

Buller now began to press his advance on the Tugela and his searchlight was seen nightly, communicating with the besieged in Ladysmith. On 10 December 1899, a heavy bombardment was heard from the Tugela. A colleague called up Pienaar from the telegraph office: "Buller has tried to cross the river; he is being driven back. Ten of his guns are in danger; and as soon as the sun sets our men are going over to take them". Pienaar went off on the road towards Colenso, determined to see those guns being taken. After four hours' riding, he arrived at a Red Cross tent and saw an ambulance wagon bringing in a few wounded soldiers. He must have been close to the battlefield now, but he heard no firing.

Half an hour further, he saw the fires of a small camp in a gully to his left and heard Dutch spoken. There he saw
Commandant Chris Botha who told him that they had taken those ten guns earlier in the afternoon.

At the camp the Boers held six Connaught Rangers - a Captain, a Lieutenant and four men. They, alone of all their regiment, had managed to reach the banks of the Tugela-Bridle Drift, about two hundred yards from the trenches of the Swaziland commando. Finding no shelter on the river bank, ex-

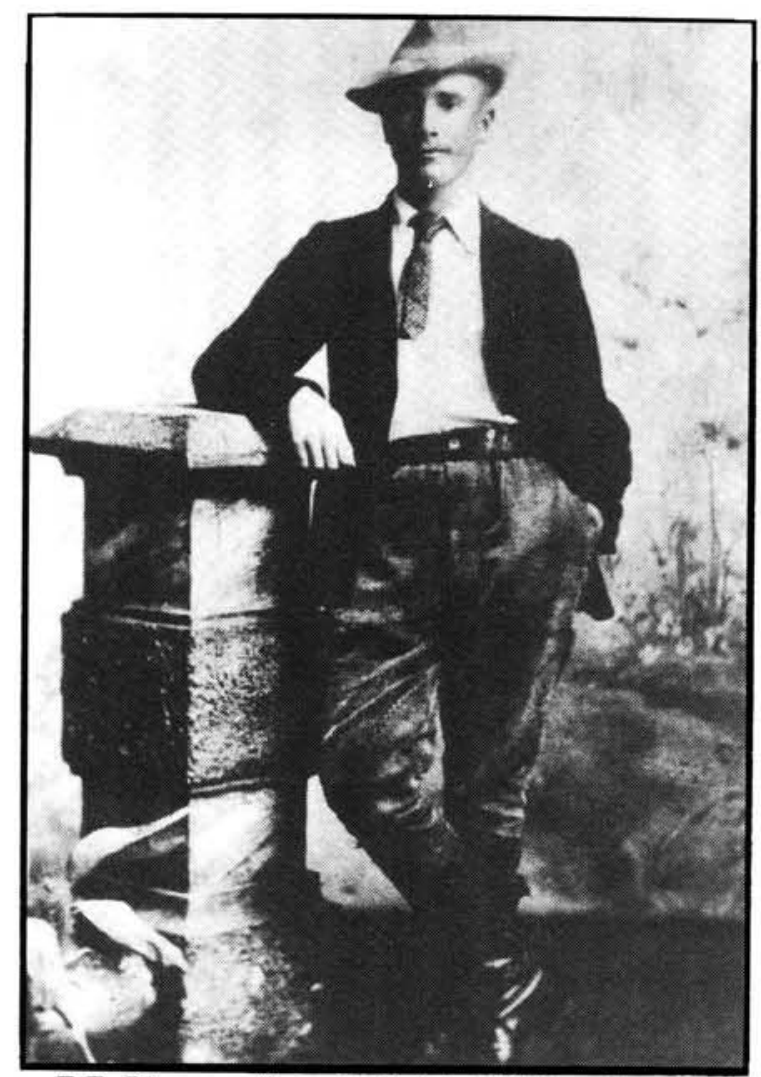

F.F. Pienaar, (later Lt Col in UDF) as burgher during the Anglo-Boer War.

hausted and wounded almost to a man, they ceased firing. whereupon our men left them in peace until the end of the fight, when they were brought over and complimented on their pluck.

Early the next morning, Pienaar together with some of Botha's men, waded through he river, wearing only hat and shirt, and carrying their top boots over the shoulder. Dozens of Boers were splashing about in the water, enjoying themselves like schoolboys. Lying strewn about on the other side, were scores of dead bodies; a little pile of empty cartridge cases lay by the side of each fallen soldier showing how long he had battled before meeting his doom. Some lay with faces serenely upturned to the sky, others were doubled up in the agony of a mortal wound, with teeth fixed in a horrid grin, foam-flecked lips and widely staring eyes. Most awful of all was the sickening stench of human blood. Pienaar and the men soon turned back, unable to bear it any longer.

"Did your commando lose many men?" Pienaar asked his companion. 
"Only two, can't explain it"

"How did you feel during the fight?"

"When we saw the vast number of soldiers approaching and heard the explosions of shells, we knew we were in for a hot time. Our small commando could never have retreated over the four miles of open country behind us. There was only one thing to be done fight. And we fought - fought till our gun-barrels hurt our hands and our throats were parched with thirst."

"Could you see when your bullet went home?"

"You notice that soldier laying behind the antheap, a hole in his forehead? That man worried us a good deal. He could shoot, the beggar! Well, two of us fixed our rifles on the sport and waited till he raised his head; then we fired. You see the result".

Pienaar rode over to the telegraph office a few miles lower down. The chief there immediately put him to work. Pienaar wired to his field cornet at Ladysmith, saying he was unavoidably detained. The next weeks passed pleasantly enough; long hours and hard work but also pleasant companions and a splendid river, with boating and swimming galore.

One morning a score of Danie Theron's scouts passed by, their famous captain at their head. One of them - an old friend - reined in long enough to tell Fienaar they were going to set an ambush for a British patrol which, according to their native spokesman, would pass a suitable spot.

During the afternoon the band returned, several on foot, and carrying someone in a blanket - none other than poor Harry C.! They had been deceived by the Black and it was the British who caught the Boers in the ambush. Pienaar's friend had received a bullet through the stomach, a wound which appeared fatal. He was laid down in a tent. Theron bent over him. his eyes full of tears. "How now, Harry?" "Awful pain captain".

Pienaar wired home that Harry had only been slightly wounded. This turned out to have been wise, for, to everybody's joy, Harry lingered on, rallied and finally recovered.

\section{PLATRAND TO GLENCOE}

Although the situation in Natal was satisfactory, the course of events elsewhere had made it imperative that the Boers capture Ladysmith at an early date. An attack on Platrand (Wagon Hill), which dominated Ladysmith, was called for this time. The plan of attack was for the Free Staters to climb the one side, the Transvalers the other, and General Louis Botha ${ }^{5}$ would ride over from Colenso with a reserve of three hundred men.

Pienaar was taken along with his chief and in the afternoon of 5 January 1900, they took the road to Ladysmith in a light mule-wagon. After having tented for the night they saddled their horses at $3 \mathrm{am}$ and followed the spoor of the commando. Upon encountering a black man holding half a dozen horses, they asked him where the owners were. He pointed to a hill nearby, where Pienaar and companions found the gallant French Combat General, de Villebois Mareuil, ${ }^{\circ}$ Oberst Von Braun, and Von Brusewitz. Little did they know at the time that the last would meet his death a few weeks later on Spioenkop and the first at Boshoff on 5 April 1900!

It was growing light and they could see, lying on their right, the neutral camp; further away, on Bulwana, the Boers biggest gun, where they knew General Joubert was standing, his wife by his side. Straight before them lay the key to Ladysmith : Platrand, whence now and again came the sharp rat-tat of the Lee-Metford, followed by the Mauser's significant cough.

Through their glasses they saw helmeted men slowly retreating up the mountain, pausing every dozen yards to fire a volley at some invisible enemy. Three of them reached the top. The sentries were ridden in. General Botha now arrived with the reserve force. All dismounted. "Put your horses out of sight" he commanded, "they will draw the enemy's fire". 
He had scarcely spoken when a shrapnel shell burst overhead, and three horses were seriously injured. Then came another and another. Both went wide. The animals were quickly led behind the hill, and the three wounded horses put out of their misery.

The attack was now in full swing: the grating British volleys, the ceaseless mill of independent firing, the short flash of the British guns, the fierce whirr of the French shells of the Boer forces, and the deep boom of Long Tom resounding through the valleys.

Hardly a single combatant could be seen: everybody was using cover. Only one soldier stood in plain view on the crest of the hill, signalling with a flag. The Boers reached the crest and the soldier disappeared. But British reinforcements presently reached the hill. In long, thin lines of yellow they ran across the plateau to the crest, hoping to drive the Boers back. As it approached the line grew thinner and thinner, until there was nothing of it left.?

For hours the yellow lines of gallant men flung themselves into the open, only to fall beneath the raging fire poured upon them from the mountain crest.

The Boer wounded came back down the hill, thirsty men, pale men, men covered with blood and weeping with rage. One man was brought down lying across a horse. His face hung in strips, shattered by a dum-dum bullet. Some of the Boers now also began using buckshot!

A Boer mounted a wagon. "Who will take in ammunition?"

No response.

Pienaar turned to his chief: "Would you advise me to try?"

"You must decide for yourself".

Throwing a bag of cartridges over his horse's back. Pienaar set off. No sooner in the open, than whizz, whizz, went bullets past his ears. The pony stopped, confused. Pienaar dug the spurs into the horse's flanks and on they went, the rapid motion, the nov- elty of the affair and the continual whistle of the bullets producing a peculiar feeling of exaltation.

Then the bag tumbled off. Pienaar sprang down, hooked the bridle to a tree, rushed back for the bag, and started forward again. The firing now became so severe that he raced for a clump of trees to find temporary shelter. Some Boers, firing at the enemy intermittently, advised Pienaar to wait a while and see how things went. He lay down under the trees. The roar of the artillery must have lulled him to sleep for he was rudely woken up. "Wake up! They're coming round to cut us off. We must clear off!" Pienaar led his pony away when suddenly all hell broke loose. It seemed as if the entire British Army was bent on his destruction. Like raindrops on a dusty road the bullets struck around him. As he struggled on Pienaar thought what a cruel shame it was that he should be shot at like a deer. Finally, the shelter of a dry watercourse was reached and after following this for some distance, Pienaar encountered another party of Boers to whom he handed his charge, too shaken to repeat the experiment. He returned to his chief mortified by his failure. The hill could not be taken that afternoon nor late that evening.

Colonel de Villebois Mareuil passed and reported that the Boer forces had been withdrawn and General Botha ordered to Colenso, where Buller had made a feint attack to help Ladysmith. In the British camp at Chieveley the naval guns still flashed by day, the searchlight still signalled to Ladysmith at night, the tents still glistened in the sun, but where had all the soldiers gone?

They were marching up the river. General Sir Redvers Buller ${ }^{8}$ intended to try his luck once more. Buller was no mere theoretician, here in Natal he had gained his Victoria Cross against the Zulus. The commandos on the Boer side of the river were extended to keep pace with the enemy's movements on the other. As the distance between the different laagers lengthened speedily certain communications be- 
came vital. For this, use was made of the vibrator, an instrument so sensitive that the most faulty line would carry enough electricity to work it. Pienaar accompanied the construction party, a vibrator strapped to the saddle. Half a dozen black men went with them carrying rolls of "cable", wire about the thickness of the lead in a pencil and covered with gutta percha. A wooden "saddle" holding one roll of wire was strapped onto the back of one of the carriers, one end of the wire joined to the back of another one of the carriers, one end of the wire joined to the instrument in the office; the carrier marched forward, the wire unrolling as he went, and the other carriers placing stones upon it here and there in order to prevent its being dragged about by cattle. In this way they went forward, establishing an office at every laager on the way, so that every commando was always fully informed about the others and the enemy's every movement immediately known to the entire forces, enabling reinforcements to be sent anywhere. It was said, perhaps frivolously, that some of the Boer generals became so fond of the system that the slightest movement of the enemy was the signal for a request for reinforcements. ${ }^{9}$

After trying for two days and finding that the Standerton laager had already shifted, they arrived at the Johannesburg laager and Pienaar had the pleasure of breakfasting with Commandant Ben Viljoen. ${ }^{10}$ The General in charge of these positions was kindhearted, energetic General Tobias Smuts, "1 of Ermelo.

During the night General Louis Botha arrived, accompanied only by his aide and his secretary. He, Smuts, and both their staffs, all slept in one small tent on the hard ground with hardly enough room to turn round in.

Pienaar's office was now in full swing and one afternoon he was honoured by a visit from a Dutch Jew and Transvaal journalist, whose articles had more power to sting the uitlanders than almost anything imaginable. ${ }^{12}$ As they drank tea in full view of the hill on which the British guns had been dragged a few days ago, the shriek of an approaching shell was heard. Nearer and louder until -bang!- the shell burst not a hundred yards away. A young linesman, who had been listening with ever widening eyes, gave an unearthly yell and almost sprang through the top of the tent, knocking over the unhappy journalist and sending the hot tea streaming down his neck!

\section{SPIOENKOP}

As the office was hastily removed to the high bank of the adjacent stream, Pienaar was ordered to leave forthwith for the Spioenkop Office. On his way there he came under constant fire. He reached Spioenkop, took charge of the office, and was kept so busy that for a week there was no time for a decent wash. The shells fell at a rate of more than sixty a minute and down on the plain they could see the British regiments drilling on the banks of the river, about two thousand yards away, probably to draw the Boer fire.

For some time the enemy's infantry had been harassing the Boers every day and drawing a little nearer every night. Louis Botha's secretary one evening said to Pienaar "It has all been in vain! Our men are worn out. They can do no more". "Cheer up" Pienaar said "There are other hills". "Tomorrow will tell" he said. And it did. In the grey dawn two hatless and bootless young men stumbled down into the laager.

"The British have taken the hill!"

Startled the others gazed at Spioenkop's top, covered by a thick mist. The British were there and as soon as the mist started clearing away ... the guns were trained on the spot and the men placed in position.

But when Pienaar ran to telegraph to Colenso, the line had been cut. "Go

\footnotetext{
F.F. Pienaar : With Steyn and De Wet, p.34.

Commandant Ben J. Viljoen (1868-1917).

General Tobias Smuts (1861-1916).

F.F. Pienaar: With Steyn and De Wet, p.36.
} 
and repair the line" said the chief. The mist cleared as Pienaar rode out, and the fight began. The cable ran about a thousand yards behind the Boer firing line and as Pienaar went on the noise of battle deafened his ears and jagged pieces of shell came whizzing past.

In the afternoon the Johannesburg laager was reached. Here a despatch rider said that reinforcements had arrived at Spioenkop early in the morning, that the Boers had climbed the hill but might have to retreat during the night. Pienaar repaired several faults and rode back to Spioenkop only to find the laager deserted, with some bodies lying in tents. The enemy had unexpectedly retired during the night, and the entire commando was now on the hill, gazing at the plentiful harvest reaped by the Maxim Nordenfeldts.

It was a mournful sight; British ambulance men were collecting all the corpses apparently without even having asked General Louis Botha for permission. Pienaar wired the news of the victory to Pretoria.

Late that afternoon Pienaar heard someone asking where the hospital was. It was his father. They had never expected to meet each other as Pienaar had parted from him in Johannesburg before the war began. Old General Pienaar, himself, was under the impression that his son was still at Ladysmith.

General Pienaar told his son that he had come to see his young nephew Johannes, who had been wounded on spioenkop the day before. They walked over to the hospital where the wounded lad, only fifteen, lay looking terribly exhausted, his left arm shattered.

"We were two together", he said, "myself and another boy. We crept closer and closer to one of the small sangars, firing into them as we crept, until there was only one Englishman left alive in it. He called out 'water!' and I ran to give him my flask. When I got close to him he pointed his gun at me and fired. I sprang aside and the bullet ploughed up my arm. My chum then shot him dead. Our doctor was too busy with the English officers to attend to me, so I fear I shall lose my arm".

His arm was amputated and he went to his uncle's farm to recuperate. Johannes Pienaar, however, would not surrender when the British arrived there, but took his gun and went on commando. Three days later he was brought in, shot through the legs. That was the last Filip Pienaar heard of his cousin.

The deserted houses in the neighbourhood had all been visited in turn by both British and Boer patrols, and between the two enormous damage had been wrought. Whereas the mischief done by the Boers was in no way authorised, it was against express orders; the British burned the Boer houses to "the joyful fiddling of the London Times and with a righteous unction eminently national".

\section{VAALKRANTZ}

About this time an engagement, known as the battle of Vaalkrantz, took place in which a portion of Viljoen's men suffered heavily.

A detachment, about forty in number, was guarding a Nordenfeldt, stationed in an advanced position on an isolated hill. One afternoon a large body of the enemy suddenly attacked the hill. Commandant Ben Viljoen, not an excessively pious man, rose to the occasion and inspired his little band by asking them if they did not fear God more than the British. The men bravely held the hill until half their number were killed. No white flag was hoisted. The Boers generally preferred certain death to surrender. Every man got out as best as he could, Commandant Viljoen himself racing out with the gun. ${ }^{13}$

The Boer guns there shelled the hill furiously. The bombardment lasted two days, after which the enemy retired and the Boers retook the hill. Two or three of the wounded were found to be still alive, with their wounds in a terrible state of putrefaction.

\footnotetext{
F.F. Pienaar: With Steyn and De Wet, p.45.
} 
When they heard that their son had gone safely through the battle of Spioenkop, an old Free State farmer and his wife came down to pay him a visit. The son then went home with his mother, the old man taking his son's place for a few days. Some artillerymen were engaged in their favourite pastime of burning out unexploded lyddite shells, when one of the shells burst, killing two of them and the old man.

While the rifles of the killed and wounded soldiers on Spioenkop were being collected, one of the rifles lay under a corpse. Seizing the weapon by the muzzle, a young Boer attempted to draw it towards him. The charge went off and lodged in his stomach, inflicting a fatal wound. The soldier had been killed in the act of taking aim, and his finger had stiffened round the trigger.

When the British retreated from Spioenkop it was to move down to Colenso. Taking the Boschrand, after a feeble defence, they were able to command the Boer positions on the other side. and succeeded in crossing the Tugela unhindered.

\section{GENERAL WITHDRAWAL FROM LADYSMITH}

Following the British advance on Kimberley, the Boers came to accept that they would have to give up Ladysmith. The men were drawn back from the river as a preparation to a general retirement. ${ }^{14}$ Pieters' Heights were held till everything was ready, and then the retirement was effected without even an attempt at pursuit by the enemy. Pienaar was ordered to reach Pieters' Heights and on arriving there he took charge of the telegraph office in General Lukas J. Meyer's ${ }^{15}$ laager. General Meyer was a grand looking man, formerly having had much influence, having at one time acted as president of the New Republic, a tract of land granted to him by a black chief for assistance rendered during a tribal war.
This small republic was soon incorporated into the Transvaal and represented by Meyer in the First Volksraad, where General Louis Botha was a member of the Second Chamber. At the Battle of Dundee (1899) Botha distinguished himself, while Meyer did not. Botha then gained fresh laurels at Colenso, finally giving him the precedence over Meyer, who was left in charge of only this laager. Meyer was therefore under the overall command of General Botha, while Commandant General Joubert was at headquarters near Ladysmith.

The British stormed every day, only to melt away before the fire of the Boers. The slaughter continued until one afternoon the enemy took the Krugersdorp Commando's position, rendering the entire line untenable.

A general council of war was held that evening, attended by moody Schalk Willem Burger, ${ }^{16}$ now Acting President, the masterful Lukas Meyer and Louis Botha, the soldier and gentleman. General Joubert was consulted throughout the discussion by telegraph. There was, therefore, no sleep for Pienaar and the other telegraphers! News then came that the Johannesburg Laager had been surrounded by the enemy. Albeit unconfirmed, it had some influence on the decision to abandon Ladysmith.

After a long and weary trek in the rain in open trucks, Glencoe was reached. General Louis Botha was still near Ladysmith with the rearguard. Most of the other chiefs were still coming by road and no one was on the spot to back up General Joubert in his attempts to reorganise the confused and ever growing mass of undisciplined men.

It had degenerated into a reckless flight. At Glencoe, President Kruger ${ }^{17}$ addressed the burghers leaning out of the window of his railway carriage, after calling them together and asking all to join in a psalm and offering up a fervent prayer for guidance. He re-

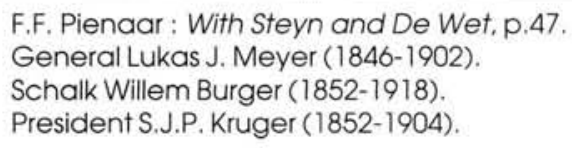


proached them for their want of faith in an all-powerful Providence, exhorting them to take courage afresh and continue the struggle for the sake of their posterity, whom one day would judge their acts. "The man who surrenders", he said "takes the first step into exile. Brothers! Stand firm, and you will not be forsaken!" And as the father of the people spoke, the doubts and fears disappeared and every man felt the glorious fires of patriotism rekindle in his bosom. ${ }^{18}$

The men received a new lease on life. The news of the surrender of Gen P.A.
Cronjé ${ }^{19}$ did not even have a permanent effect. Pienaar was sent down to Nqutu, Zululand, and there received the news of the fall of Bloemfontein, the death of General Joubert, and of De Wet's victory at Sannaspos. He briefly visited Johannesburg where, after the Boer defeats, many Smits became Smiths, Louw shrank into Lowe, Jansen transformed into Johnson, and Volschenk became Foolskunk. What did John Bull think of all these precious acquisitions to his family!

* Brig (Dr) J.H. Picard SM, is Director Language Service, SADF.

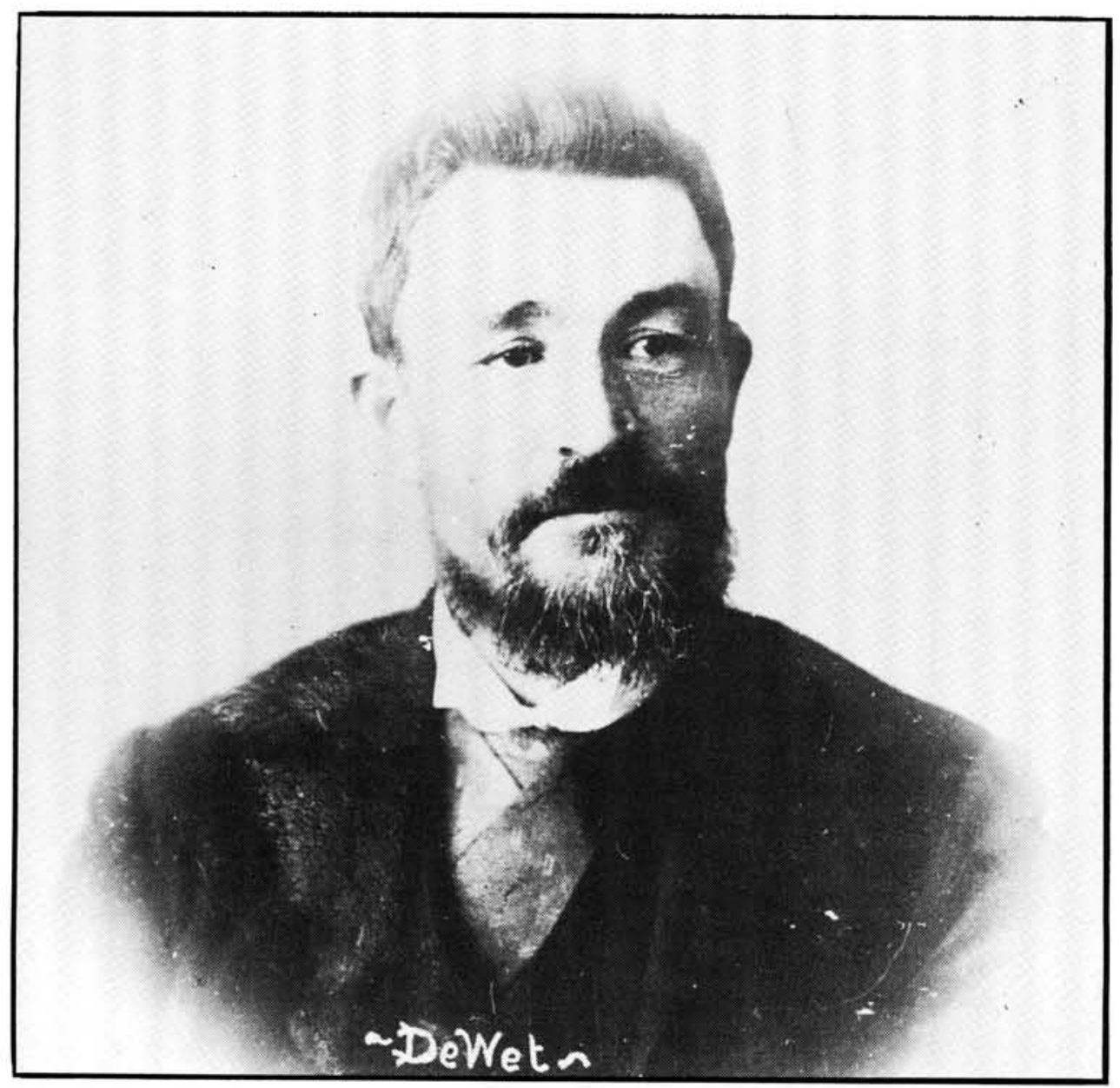

General C.R. de Wet.

Acknowledgement:

Photographs supplied by SADF Archives 